\title{
BENZAMIDE DERIVATIVES AS POTENTIAL CANDIDATES FOR ANTI-ALZHEIMER, ANTI-FATIGUE, ANTI-UREASE AND ANTI-OXIDANT ACTIVITY
}

\author{
M. B. TAI I* S. A. TIRMIZI I*, A. RAHEEL I, H. B. M. ALI', S. QURESHI , H. ALSHATIR ${ }^{4,5}$ \\ ${ }^{\prime}$ Department of Chemistry, Quaid-e-Azam University, Islamabad, Pakistan \\ ${ }^{2}$ Department of Chemistry, University of Malaya, Kualalampur, Malaysia \\ ${ }^{3}$ Department of Chemistry, Islamia University, Bahawalpur, Pakistan \\ ${ }^{4}$ Department of Chemistry, Khalias Jeddah University, Jeddah, Saudi Arabia \\ ${ }^{5}$ Forensic and Toxicology Department, ElMounfia University, Egypt
}

\begin{abstract}
Benzamide derivatives were screened for their anti-alzheimer, anti-fatigue, anti-urease and anti-oxidant activity and their results were calculated in the form of \%age inhibition and $\mathrm{IC}_{50}$ value. Compounds $3 \mathrm{a}$ and $3 \mathrm{~g}$ exhibited the highest anti alzheimer activity. Group of mice's treated by compounds $3 \mathrm{f}$ and $3 \mathrm{~g}$ showed significantly longer swimming times than those of the treated with caffeine. The prominent urease inhibitory activity was shown by only one compound among seven benzamide derivatives. Controlled experiments suggest that benzamide derivatives $(3 \mathrm{a}-3 \mathrm{~g})$ can be serve as the therapeutic agents
\end{abstract}

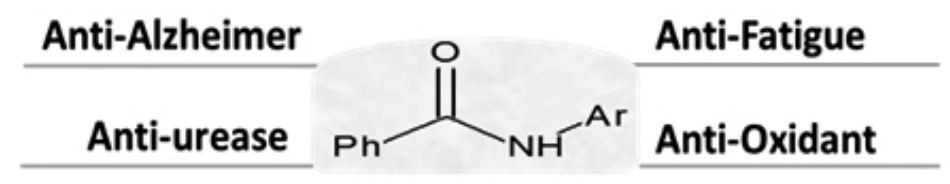

\section{INTRODUCTION}

The amide bond is an important pharmacophore group present in a wide variety of therapeutically important drugs e.g. buspirone [1], ampakine and phosphoramide compounds. The ampakine compounds containing benzamide core are used to improve learning, memory [2] and in the treatment of neurodegenerative disorders, cognitive impairment, depression, Alzheimer's disease and schizophrenia [3]. The roles of cholinesterase inhibitors in alzheimer's disease are still not completely unveiled, focus the attention of biologists and chemists on the modification of amide bond for the development of biological, pharmaceutical and clinical compounds. Recently, it was shown that some benzamide derivatives exhibited good inhibitory potency towards acetylcholinesterase [4].

Phenyl phosphorodiamidates and phosphoric monoamide inhibit metalloenzyme urease (urea amidohydrolase) by forming a chelated complex with the nickel ion in the active site of enzyme [5].

According to B. Pasteurii, diamidophosphate inhibition involves inhibitor oxygen binding to nickel-1 and amide coordinates to nickel-2 mimicking the substrate bounded structure [6,7]. Several classes of compounds have been reported as the agents having anti-urease activity; among them hydroxamicacids are the best recognized urease inhibitors (8-10). However, the teratogenicity of hydroxamicacid in rats and degradation of phosphoramidates at low $\mathrm{pH}$ $(8,11,12)$ restrict their use as a drug in vivo.

Free radical formation is associated with the normal natural metabolism occurring in aerobic cells. Owing to the oxygen consumption inherent in cell growth a series of oxygen free radicals such as hydroxyl (OH.), superoxide anion $\left(\mathrm{O}^{-2}\right)$, nitric oxide $(\mathrm{NO})$ and peroxyl $\left(\mathrm{RO}^{2}\right)$ spontaneously occur and these reactive oxygen species (ROS) are involved in different physiological process $[13,14]$. The protection of biological molecules (lipids, carbohydrates, proteins and DNA) from oxidative stress is very important to prevent inflammatory diseases, atherosclerosis, aging and cancer caused by high levels of ROS [15]. Antioxidants scavenge and prevent the formation of free radicals. The main characteristic of an antioxidant is its ability to trap free radicals. So they are highly important for the treatment of these kinds of diseases. For this reason, in recent years, there has been an increasing interest in the use of synthetic oxidants [16]. DPPH is widely used to test the ability of compounds to act as free radical scavengers or hydrogen donors. The DPPH method can be used for solid or liquid samples and is not specific to any particular antioxidant component, but applies to the overall antioxidant capacity of the sample.

This work is extension of our research on benzamide nucleus. Here we are just focusing on investigation of the anti-alzheimer, anti-fatigue, anti-urease, and anti-oxidant properties of already synthesized benzamide derivatives (3a-3g) [17]. Detailed results and discussion are elaborated in the following sections.

\section{MATERIALS AND METHODS}

\subsection{Anti-Alzheimer activity}

In anti-alzheimer activity method, the total volume of the reaction mixture was $100 \mu \mathrm{L}$. It contained $60 \mu \mathrm{L} \mathrm{Na}_{2} \mathrm{H}_{2} \mathrm{PO}_{4}$ buffer with concentration of $50 \mathrm{mM}$ and $\mathrm{pH}$ 7.7. $10 \mu \mathrm{L}$ test compound $\left(0.5 \mathrm{mM}^{4}\right.$ well $\left.^{-1}\right)$ was added, followed by the addition of $10 \mu \mathrm{L}\left(0.005\right.$ units well $\left.{ }^{-1}\right)$ enzyme. The contents were mixed and pre-read at $405 \mathrm{~nm}$. Then contents were pre-incubated for $10 \mathrm{~min}$ at $37^{\circ} \mathrm{C}$. The reaction was initiated by the addition of $10 \mu \mathrm{L}$ of $0.5 \mathrm{mM}^{\circ}$ well ${ }^{-1}$ substrate (acetylthiocholine iodide). After $15 \mathrm{~min}$ of incubation at $37^{\circ} \mathrm{C}$ absorbance was measured at $405 \mathrm{~nm}$ using 96-well plate reader Synergy HT, Biotek, USA. All experiments were carried out with their respective controls in triplicate. Eserine $(0.5 \mathrm{mM}$ well-1 $)$ was used as a positive control. The percent inhibition was calculated by the help of following equation [18].

$$
\text { Percent inhibition }=\left[\frac{\text { Control }- \text { test }}{\text { Control }}\right] \times 100
$$

Where

Control $=$ Total enzyme activity without inhibitor.

Test $=$ Activity in the presence of test compound.

\subsection{Anti-Fatigue Activity}

Animals Six-week-old male Kunming mice (18-22 g, specific pathogenfree grade, SPF) were obtained from the Academy of Experimental Animal Center of the Fourth Military Medical University (Xi'an, China). Mice were maintained under normal conditions: $21-26^{\circ} \mathrm{C}$ temperature, $60 \%-70 \%$ relative humidity, $12: 12 \mathrm{~h}$ dark/light cycle, and free access to laboratory standard diet and water. All mice were quarantined and adapted for 7 days after arriving. All animal experiments were conducted under institutional guidelines and approved by the Ethical Committee for Animal Care and Use of the Fourth Military Medical University. The anti-fatigue activity of benzamide derivatives was evaluated by the weight loaded swimming model in mice. The model is a reliable measure of anti-fatigue treatment as established in both laboratory animals and humans [19-21]. All mice were randomly divided into 9 groups, two control groups and seven treatment groups, five mice per group. Benzamide derivatives were dissolved in carboxymethylcellulose sodium (CMC) $5 \mathrm{~g} / \mathrm{L}$ aqueous solution, respectively. One control group received the same volume of saline solution. Another control group received caffeine as a positive control group. Benzamide derivatives were given to mice at concentrations of 0.1 mmol/kg body weight. Samples were orally administered into mice using a feeding atraumatic needle, once per day at 1:00-3:00 pm for one week. After each treatment, all groups of the mice were allowed to rest 30 min and were forced to swim for ten minutes to become accustomed to swimming. The size of swimming pool was designed as $50 \mathrm{~cm} \times 50 \mathrm{~cm} \times 40 \mathrm{~cm}$, filled with fresh 
water at $30 \pm 2{ }^{\circ} \mathrm{C}$. A tin wire ( $5 \%$ of body weight) was loaded on the tail root of the mouse. The mice were assessed to be exhausted when they failed to rise to the surface of water to breathe within a $7 \mathrm{~s}$ period [22]. At the end of the session, the mice were removed from the water, dried with a paper towel, and placed back in their home cages. Water in the container was drained after each session. The swimming time to exhaustion was used as the index of the forced swimming capacity.

\subsection{Anti-urease activity}

In anti-urease activity method [23], a total volume of $85 \mu 1$ mixture contained $10 \mu \mathrm{l}$ of phosphate buffer of $\mathrm{pH} 7.0$ in each well in the 96-well plate followed by the addition of $10 \mu$ of sample solution and $25 \mu$ l of enzyme solution (0.134 7 units). Contents were pre-incubated at $37{ }^{\circ} \mathrm{C}$ for 5 minutes. Then, $40 \mu \mathrm{l}$ of urea stock solution $(20 \mathrm{mM})$ was added to each well and incubation continued at $37^{\circ} \mathrm{C}$ for further $10 \mathrm{~min}$. After given time, $115 \mu \mathrm{l}$ phenol hypochlorite reagent was added in each well (freshly prepared by mixing $45 \mu 1$ phenol reagent with $70 \mu \mathrm{l}$ of alkali reagent). For color development, incubation was done at $37^{\circ} \mathrm{C}$ for another $10 \mathrm{~min}$. Absorbance was measured at $625 \mathrm{~nm}$ using the 96-well plate reader Synergy HT. The percentage enzyme inhibition was calculated by the following formula [24].

$$
\text { Percent inhibition }=\left[\frac{\text { Abs. of test compd. }}{\text { Abs.of control }}\right] \times 100
$$

\subsection{Anti-Oxidant activity}

The stable 1,1-diphenyl-2-picrylhydrazyl radical (DPPH) was used for the determination of antioxidant activity. Different concentrations of compounds in respective solvents were added at an equal volume $(10 \mu \mathrm{l})$ to $90 \mu \mathrm{l}$ of $100 \mu \mathrm{M}$ methanolic DPPH in a total volume of $100 \mu 1$ in 96 -well plates. The contents were mixed and incubated at $37^{\circ} \mathrm{C}$ for 30 minutes. The absorbance was measured at $517 \mathrm{~nm}$ using Synergy HT BioTek® USA microplate reader. Quercetin and L-ascorbic acid were used as standard antioxidants. The experiments were carried out in triplicates. $\mathrm{IC}_{50}$ values were calculated using EZ-Fit5 Perrella Scientific Inc. Amherst USA software. The decrease in absorbance indicates increased radical scavenging activity which was determined by the following formula [25].

$$
\begin{aligned}
& \text { Percent scavenging activity } \\
& \qquad=\left[100-\frac{\text { Abs. of test compd. }}{\text { Abs.of control }}\right] \times 100
\end{aligned}
$$

\section{RESULTS AND DISCUSSION}

\subsection{Anti-Alzheimer activity}

The inhibitory activities of the benzamide against standard drug, Eserine is measured. Compounds $3 \mathrm{a}$ and $3 \mathrm{~g}$ exhibited the highest activity which could be ascribed to the increased of resonance effect caused by electrons of the nitrogen attached linked with aromatic ring [26].

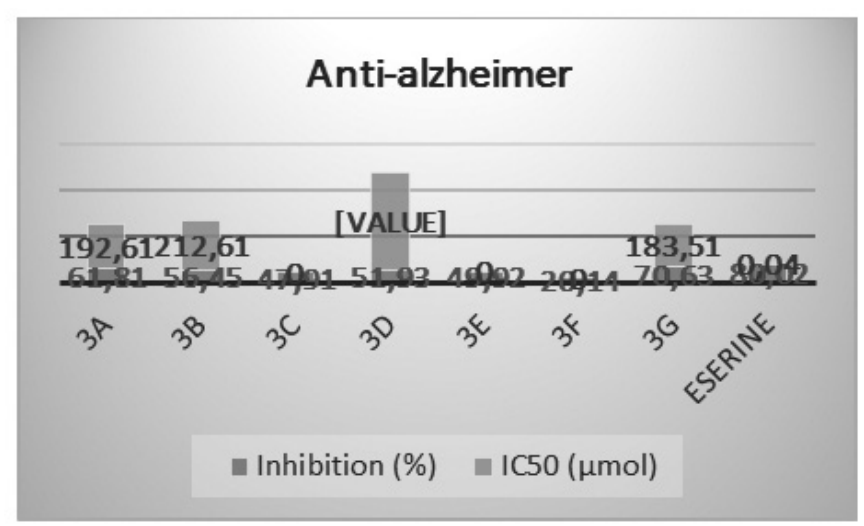

Fig. 1 Anti-alzheimer activity of benzamide (3a-3g).

Compounds 3b, 3d, 3e showed more than $30 \%$ inhibition at final concentration of $0.5 \mathrm{mM}$.

The least active compound ( $3 \mathrm{f}$ ) showed only about $20 \%$ inhibition at a final concentration of $0.5 \mathrm{mM}$. This may be due to the replacement of one phenyl ring with thiadiazole ring in the compound. These findings agree well with previous report in which electron-withdrawing group exhibited greater reduction in the inhibitory activity [27]

\subsection{Anti-Fatigue Activity}

The forced swimming capacities are shown in Fig. 2. There are significant differences in the swimming time to exhaustion between the control group and each treatment group. The swimming times to exhaustion of the caffeine (positive control group), 3f and $\mathbf{3 g}$ groups were $1300 \pm 85 \mathrm{~s}$ and $1280 \pm 123 \mathrm{~s}$ respectively. Thus, the swimming times to exhaustion of the $\mathbf{3 f}$ and $\mathbf{3 g}$ groups were significantly longer than those of the caffeine group It is worthwhile to note that $\mathbf{3 f}$ and $\mathbf{3 g}$ have a common thiazole group. But what is the real reason? Further observation and study are needed. On the other hand, the swimming times to exhaustion of the $\mathbf{3 a}, \mathbf{3 b}, \mathbf{3} \mathbf{c}$ and $\mathbf{3 e}$ groups were longer than that of the normal saline group. However, there was no significant difference in between the caffeine group and each of the other treatment groups.

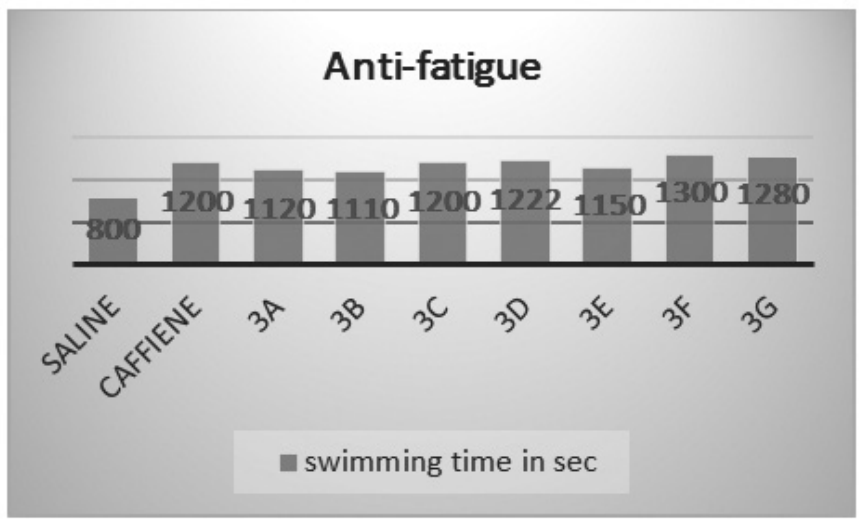

Fig. 2 Anti-fatigue activity of benzamide (3a-3g)

\subsection{Anti-urease activity}

Almost all the compounds show moderate to good urease inhibitory activity (Fig. 3). Lower $\mathrm{IC}_{50}$ value indicate higher inhibitory activity. Compound $3 \mathrm{a}$ proved to be the most potent showing an enzyme inhibition activity with an $\mathrm{IC}_{50}=4.51$ which is may be due to the presence of two nitrogens in the ring. The compound $3 \mathrm{~d}$ showed least inhibition activity with an $\mathrm{IC}_{50}=134.3$ which is may be due to the presence of naphthalene ring in the compound.

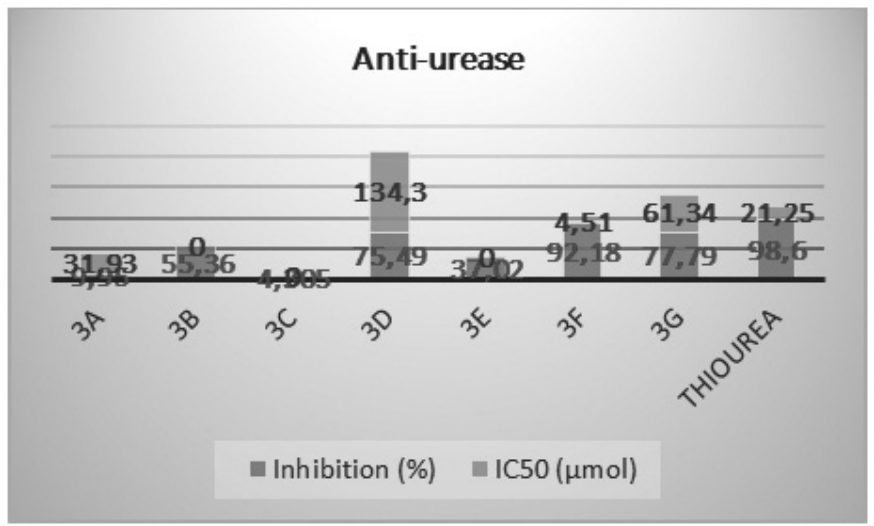

Fig. 3 Urease inhibitory activity of benzamide (3a-3g)

3.4. Anti-Oxidant activity

A simple method that has been developed to determine the antioxidant activity of compounds utilizes the stable 2,2-diphenyl-1-picrylhydrazyl (DPPH) radical. The structure of DPPH and its reduction by an antioxidant are shown in Fig. 4. 


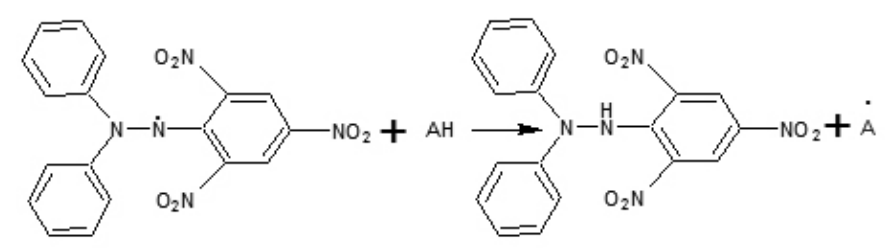

Fig. 4 DPPH radical reduction by compound, AH

Free radical scavenging properties of the benzamide derivatives $(3 a-3 g)$ were also determined by observing the interaction with stable free radical DPPH (2,2-diphenyl-1-picrylhydrazyl). There are no noteworthy results obtained with DPPH.

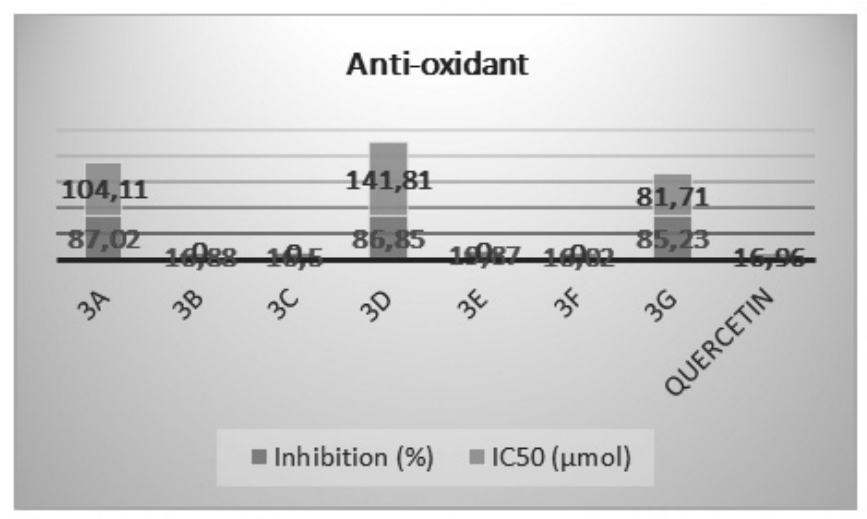

Fig. 5 Anti-oxidant activity of benzamide (3a-3g)

\section{CONCLUSIONS}

The results from this study conclusively demonstrate the anti-alzheimer, anti-fatigue, anti-urease, and anti-oxidant activity of benzamide derivatives. Antioxidant activity of benzamide derivatives is not significant. Compounds $3 \mathrm{a}$ and $3 \mathrm{~g}$ show good anti-alzheimer activity while the swimming times to exhaustion of the $\mathbf{3 f}$ and $\mathbf{3 g}$ groups were significantly longer than those of the caffeine group. Compound $3 \mathrm{a}$ can be used as potent urease inhibitor. Therefore, they might serve as therapeutic agents, particularly for the treatment of Alzheimer's disease and Urease disorders.

\section{ACKNOWLEDGEMENTS}

This work was supported by IRSIP under Higher Education Commission of Pakistan (HEC), Quaid-e-Azam University, Islamabad (QAU), Pakistan and University of Malaya (UM), Kualalampur, Malaysia.

\section{CONFLICT OF INTREST}

There is no conflict of interest between the Authors

\section{REFERENCES}

1. H.P. Mahana, L.G. Christian, R.A. Maturana, B.S. Claudio, C. D. P. Mahana, J. Chil. Chem. Soc. 2, 54, (2009).

2. S.A. Johnson, N.T. Luu, T.A. Herbst, R. Knapp, D. Lutz, A. Arai, G. Lynch, J. Pharmacol. Exp. Ther. 289, 392-397, (1999).

3. B.A. Bahr, J. Bendiske, Q.B. Brown, S. Munirathinam, E. Caba, M. Rudin, S. Urwyler, A. Sauter, G. Rogers, Exp. Neurol. 174, 37-47, (2002).

4. D.Y. Peng, Q. Sun, X.L. Zhu, H.Y. Lin, Q. Chen, N.X. Yu, W.C. Yang, G.F. Yang, Bioorg. Med. Chem. 20, 6739-6750, (2012).

5. R.L. Blakeley, B. Zerner, J. Mol. Catal. 23, 263-292, (1984).

6. S. Benini, W.R. Rypniewski, K.S. Wilson, S. Miletti, S. Ciurli, Structure 7, 205-216, (1999).

7. S. Benini, S. Ciurli, H.F. Notling, S. Mangani, Eur. J. Biochem. 239, 6166, (1996).

8. M. Adil, S.A. Slama, S. Mahmood, M. Shahid, A. Saeed, J. Iqbal, Eur. J. Med. Chem. 46, 5473-5479, (2011).
9. B. Krajewska, J. Mol. Catal. B. Enzym. 59, 9-21, (2009).

10. E.M.F. Muri, H. Mishra, M.A. Avery, J.S. Williamson, Synth. Commun. 33, 1977-1995, (2003).

11. M.J. Domınguez, C. Sanmartin, M. Font, J.A. Palop, S.S. Francisco, O. Urrutia, F. Houdusse, J. Garcica-Mina, J. Agric. Food Chem. 56, 37213731, (2008).

12. T. Kreybig, R. Preussmann, W. Schmidt, Arzneim Forsch 18, 645-657, (1968)

13. R. Schreck, R.A. Bauerle, Trends Cell. Biol. 1, 39-42, (1991).

14. I. Fridovich, Science 201, 875-880, (1978).

15. Y. Dong, T.K. Venkatchalam, R.K. Narla, V.N. Trieu, E.A. Sudbeck, F. Uckun, Bio. Med. 10, 87-90, (2000).

16. M.J.R.P. Queiroz, I.C.F.R. Ferreira, R.C. Calhelha, L.M. Estevinho, Bioorg. Med. Chem. 15, 1788-1794, (2007).

17. Supplementary information: Structure of benzamide derivatives.

18. G.L. Ellman, K.D. Courtney, V. Andres, R. M. Featherstone, Biochemical Pharmacology $7,88-90,(1961)$.

19. K.A. Jung, D. Han, E.K. Kwon, C.H. Lee, Y.E. Kim, J. Med. Food 10, 689-693, (2007).

20. J.M. Jia, C.F. Wu, Pharm. Biol. 46, 433-436, (2008).

21. J.T. Selsby, K.D. Beckett, M. Kern, J. Strength Cond. Res. 17, 421-424, (2003).

22. K. Jung, I.H. Kim, D. Han, J. Ethnopharmacol 93, 75-81, (2004).

23. L.V. Edgington, K.L. Klew, G.L. Barron, Phytopathology 61, 42-44, (1971).

24. M.W. Weatherburn, Analytical chemistry 39, 971-974, (1967).

25. I.I. Koleva, T.A. Van Beek, J.P.H. Linssen, A.De Groot, L.N. Evstatieva, Phytochemical Analysis 13, 8-17, (2002).

26. N. Gwaram, H.M. Ali, M. Abdulla, M. Buckle, S. Sukumaran, L. Chung, S. Abdelwahab, Molecules 17, 2408-2427, (2012).

27. S. Salga, H.M. Ali, M. Abdullah, S. Abdel wahab, L. Wai, M. Buckle, A. Hadi, Molecules 16, 9316-9330, (2011). 